\title{
Effect of Sowing Method and N Application on Seed Yield and N Use Efficiency of Winter Oilseed Rape
}

\author{
Klaus Sieling *, Ulf Böttcher and Henning Kage \\ Agronomy and Crop Science, Institute of Crop Science and Plant Breeding, Christian-Albrechts-University of Kiel, \\ Hermann-Rodewald-Str. 9, D-24118 Kiel, Germany; boettcher@pflanzenbau.uni-kiel.de (U.B.); \\ kage@pflanzenbau.uni-kiel.de (H.K.) \\ * Correspondence: sieling@pflanzenbau.uni-kiel.de; Tel.: +49-431-880-3444; Fax: +49-431-880-1396
}

Academic Editor: Bertrand Hirel Received: 2 November 2016; Accepted: 22 February 2017; Published: 28 February 2017

\begin{abstract}
In northern Europe, replacing winter barley with winter wheat as the preceding crop for winter oilseed rape (Brassica napus L.; WOSR) often results in a delayed WOSR sowing and poor autumn growth. Based on data from a field experiment running in 2009/2010, 2010/2011, and 2012/2013, this study aims (i) to investigate how a delayed sowing method affects seed yield, $\mathrm{N}$ offtake with the seeds, and apparent $\mathrm{N}$ use efficiency (NUE) of WOSR; (ii) to test the ability of autumn and spring $\mathrm{N}$ fertilization to compensate for the negative effects of a delayed sowing method; and (iii) to estimate the minimum autumnal growth for optimal seed yield. In order to create sufficiently differentiated canopies, a combination of four sowing methods (first week of August until the third week of September) and four autumn $\mathrm{N}$ treatments $\left(0,30,60\right.$, and $\left.90 \mathrm{~kg} \cdot \mathrm{N} \cdot \mathrm{ha}^{-1}\right)$ was established. Each of these 16 different canopies was fertilized with $5 \mathrm{~N}$ amounts $(0 / 0,40 / 40$, $\left.80 / 80,120 / 120,140 / 140 \mathrm{~kg} \cdot \mathrm{N} \cdot \mathrm{ha}^{-1}\right)$ in spring in order to estimate separate $\mathrm{N}$ response curves. Above-ground $\mathrm{N}$ accumulation in autumn and seed yield and $\mathrm{N}$ offtake by the seeds were determined. Plant establishment after mid-September significantly decreased seed yield. Autumn $\mathrm{N}$ fertilization of at least $30 \mathrm{~kg} \cdot \mathrm{N} \cdot \mathrm{ha}^{-1}$ increased seed yield and $\mathrm{N}$ offtake by the seeds without any significant interaction with sowing method and spring $\mathrm{N}$ supply. However, the pathway(s) remain(s) unclear. Spring $\mathrm{N}$ fertilization up to $130 \mathrm{~kg} \cdot \mathrm{N} \cdot \mathrm{ha}^{-1}$ (estimated by a Linear-Plateau $\mathrm{N}$ response curve) increased seed yield. NUE decreased with increasing $\mathrm{N}$ supply, where WOSR used autumn $\mathrm{N}$ to a lesser extent than spring N. An above-ground N uptake of at least $10-15 \mathrm{~kg} \cdot \mathrm{N} \cdot \mathrm{ha} \mathrm{a}^{-1}$ at the end of autumn growth was required to achieve high seed yields. From an environmental point of view, optimal autumn growth should be attained by choosing an adequate sowing method, not by applying additional $\mathrm{N}$ in autumn.
\end{abstract}

Keywords: oilseed rape; seed yield; sowing method; $\mathrm{N}$ fertilization; autumn $\mathrm{N}$ uptake; $\mathrm{N}$ use efficiency

\section{Introduction}

Farmers in northern Europe often replace winter barley with winter wheat as the preceding crop for winter oilseed rape (Brassica napus L.; WOSR) causing a delayed WOSR sowing due to the later wheat harvest. Luteman and Dixon [1] and Sieling et al. [2] observed a reduced autumn and winter growth by delayed plant establishment, especially if it was later than 10 September, increasing the risk of winter kill [3-5]. While Luteman and Dixon [1] found only small yield penalties, Uzan et al. [6] reported a decline in seed yield of canola cultivars with a delay in sowing date under Mediterranean environment conditions due to shortening the length of the reproductive period and consequently the potential grain-filling period. Also, Scott et al. [7] showed large yield penalties if sowing occurred after mid-September. 
In order to compensate for the poor autumn growth, an additional nitrogen $(\mathrm{N})$ supply of about $30-50 \mathrm{~kg} \cdot \mathrm{N} \cdot \mathrm{ha}^{-1}$ in autumn is intended to ensure crop $\mathrm{N}$ supply, adequate crop growth before winter and, consequently, a good overwinter survival. Autumn N, especially in early-sown oilseed rape, leads to a better above-ground growth [2] and enhances $\mathrm{N}$ accumulation before winter [8]. It is, however, debatable whether this increases seed yield and overwintering. Results of Ogilvy and Bastiman [9] revealed that, although plots receiving nitrogen in the seedbed or at the two-leaf stage were more vigorous before winter compared with unfertilized plants, neither the number of plants established, the survival over winter, nor the seed yield were affected by this treatment. According to Engström et al. [10] no effects on seed yield occurred after applying 30 or $60 \mathrm{~kg} \cdot \mathrm{N} \cdot \mathrm{ha}^{-1}$ at sowing to WOSR in Sweden. In addition, Sieling and Kage [11] observed that WOSR yield increased by $0.2 \mathrm{t} \cdot \mathrm{ha}^{-1}$ after an autumn $\mathrm{N}$ supply of $40 \mathrm{~kg} \cdot \mathrm{N} \cdot \mathrm{ha}^{-1}$. In experiments in France, severe $\mathrm{N}$ deficiencies in autumn, described in terms of the nitrogen nutrition index, reduced shoot biomass, tap root biomass, leaf area index, and radiation-use efficiency compared with $\mathrm{N}$ sufficient treatments [12]. However, no difference in seed yield occurred. The authors assumed that sufficient $\mathrm{N}$ release due to natural mineralization provided enough growth in autumn to ensure sufficient regrowth in spring. In other experiments, autumn $\mathrm{N}$ gave a small yield response where the preceding cereal straw was baled or incorporated instead of burning $[13,14]$. In addition, $\mathrm{N}$ application to boost crop growth rate may lead to plants being more susceptible to freezing in winter due to vigorous vegetative growth prior to the first killing frost or to increased leaching risk of $\mathrm{N}$ not taken up by the crop.

Spring $\mathrm{N}$ fertilization clearly increases WOSR seed yield. WOSR demands high amounts of $\mathrm{N}$ fertilizer often exceeding $200 \mathrm{~kg} \mathrm{~N} \cdot \mathrm{ha}^{-1}$ to achieve maximum yields in high yielding environments with yield levels $>4 \mathrm{t} \cdot \mathrm{ha}^{-1}$. Scott et al. [15] and Zhao et al. [16] suggested a maximum yield response to a $\mathrm{N}$ rate around $200 \mathrm{~kg} \cdot \mathrm{N} \cdot \mathrm{ha}^{-1}$, which was in good agreement with the results of Bilsborrow et al. [17] who obtained $>85 \%$ of the maximum recorded yield with an application of $150 \mathrm{~kg} \cdot \mathrm{N} \cdot \mathrm{ha}^{-1}$. Several approaches from, for example, France and Germany take the amount of N in the WOSR canopy at the end of autumn growth and/or at the beginning of spring growth into account [18-20]. In one study of insignificant leaf losses over winter, a well-developed rapeseed canopy showed a higher leaf area index at the beginning of spring growth than a poor canopy, which, in consequence, allows for reduced $\mathrm{N}$ fertilization rates [21]. Henke et al. [19] showed that even if canopy $\mathrm{N}$ is lost over winter due to frost, optimum $\mathrm{N}$ requirements in spring decreased with increasing canopy $\mathrm{N}$ in late autumn. These results assumed a negative interaction between autumn $\mathrm{N}$ supply, promoting above-ground dry matter accumulation and $\mathrm{N}$ uptake, and spring $\mathrm{N}$ application [2].

WOSR has the ability to take up more $\mathrm{N}$ than winter cereals between sowing and spring [22]; however, relatively little of this $\mathrm{N}$ ends up in the seed [23]. Compared to the $\mathrm{N}$ requirement, $\mathrm{N}$ offtake by the WOSR seeds is comparatively low, leading to low nitrogen harvest indices and high $\mathrm{N}$ balance surpluses (fertilizer $\mathrm{N}$ minus $\mathrm{N}$ offtake by the seeds), which can lead to high $\mathrm{N}$ leaching rates during periods of heavy rainfall [23-27]. Thus, along with an increasing rate of $\mathrm{N}$-fertilization, the rate of fertilizer-N recovery (apparent $\mathrm{N}$ use efficiency (NUE)) declines substantially [26]. Due to only small yield effects, $\mathrm{N}$ fertilization in autumn is less $\mathrm{N}$ efficient in spring, thus most of the autumn $\mathrm{N}$ remains in the system. In field experiments reported by Sieling and Kage [11], $40 \mathrm{~kg} \cdot \mathrm{N} \cdot \mathrm{ha}{ }^{-1}$ in autumn increased $\mathrm{N}$ offtake by the seeds by about $4 \mathrm{~kg} \cdot \mathrm{N} \cdot \mathrm{ha}{ }^{-1}$, thus $36 \mathrm{~kg} \cdot \mathrm{N} \cdot \mathrm{ha}{ }^{-1}$ were left in the soil changing the $\mathrm{N}$ balance.

In general, it is assumed that WOSR requires at least six to eight leaves, a root collar diameter of $1 \mathrm{~cm}$, a tap root length of $20 \mathrm{~cm}$, and about $1 \mathrm{~g}$ of dry matter (DM) per plant to secure optimal winter survival [28]. Under the climate conditions of northern Europe, sowing date and $\mathrm{N}$ availability in autumn are the main factors influencing WOSR growth before winter, which can be managed by the farmers [2]. However, no data are available on which to base thresholds for optimal autumn growth.

Based on data from a three-year field experiment, this study aims (i) to investigate how delayed sowing affects seed yield, $\mathrm{N}$ offtake with the seeds, and $\mathrm{N}$ use efficiency of WOSR; (ii) to test the ability of autumn and spring $\mathrm{N}$ fertilization to compensate for the negative effects of a delayed sowing 
method; and (iii) to estimate the minimum autumnal growth for optimal seed yield. We hypothesize that delaying sowing reduces seed yield, $\mathrm{N}$ offtake, and $\mathrm{N}$ use efficiency, while autumn $\mathrm{N}$ supply may increase these factors, especially in late sown canopies. In addition, spring $\mathrm{N}$ fertilization may be reduced if additional $\mathrm{N}$ was applied in autumn.

\section{Results}

The experimental design provided an increased seed density at later sowing in order to compensate for a decreased emergence rate, thus confounding both effects. However, in considering the average of the three years, plant densities were quite similar for all sowing methods ranging between 37 and 47 plants. $\mathrm{m}^{-2}$ at the end of autumn growth and between 36 and 40 plants. $\mathrm{m}^{-2}$ at the beginning of spring growth. Consequently, winter survival also remained unaffected. Therefore, no significant interaction between sowing date and seed density occurred.

\subsection{Seed Yield}

In considering the average of all three years and all other treatments, sowing in September significantly decreased WOSR seed yield $(p<0.05)$ (Table 1$)$. While both sowing methods in August resulted in similar seed yields of about $5 \mathrm{t} \cdot \mathrm{ha}^{-1}$, drilling in the first and third September week caused a yield loss of $0.3 \mathrm{t} \cdot \mathrm{ha}^{-1}$ and $1.2 \mathrm{t} \cdot \mathrm{ha}^{-1}$, respectively. Autumn $\mathrm{N}$ application significantly increased seed yield by $0.6 \mathrm{t} \cdot \mathrm{ha}^{-1}$, in comparison to the unfertilized and the $90 \mathrm{~kg} \cdot \mathrm{N} \cdot \mathrm{ha}{ }^{-1}$ treatments (Table 1). The sowing method by autumn $\mathrm{N}$ interaction was not significant at $p=0.05$.

Table 1. Sowing method by autumn $\mathrm{N}$ application interaction effects on winter oilseed rape (Brassica napus L.; WOSR) seed yield (t.ha ${ }^{-1}$ ) (based on the average of 2009/2010, 2010/2011, 2012/2013 and all spring treatments).

\begin{tabular}{cccccc}
\hline \multicolumn{6}{c}{ Autumn N Application $\mathbf{~} \mathbf{k g} \cdot \mathbf{N} \cdot \mathbf{h a} \mathbf{a}^{\mathbf{- 1}}$ ) } \\
\hline Sowing Method $\ddagger$ & 0 & 30 & 60 & 90 & Mean \\
SD 1 & 4.72 & 4.87 & 5.02 & 5.12 & $4.93^{\mathrm{a}, \dagger}$ \\
SD 2 & 4.74 & 4.94 & 5.16 & 5.18 & $5.01^{\mathrm{a}}$ \\
SD 3 & 4.05 & 4.74 & 4.86 & 4.98 & $4.66^{\mathrm{b}}$ \\
SD 4 & 3.42 & 3.71 & 3.84 & 4.06 & $3.76^{\mathrm{c}}$ \\
Mean & $4.23^{\mathrm{c}}$ & $4.56^{\mathrm{b}}$ & $4.72^{\mathrm{a}, \mathrm{b}}$ & $4.83^{\mathrm{a}}$ &
\end{tabular}

‡-SD 1-first week of August; SD 2-third week of August; SD 3-first week of September; SD 4- third week of September. ${ }^{+}$-Different letters indicate significant differences within a factor at $p=0.05$. The sowing method by autumn $\mathrm{N}$ interaction was not significant $(p>0.05)$. SD—sowing method.

Spring N supply boosted seed yield (Figure 1a; for estimated model parameters, see Table 2). However, $\mathrm{N}$ amount that exceeded $116-136 \mathrm{~kg} \cdot \mathrm{N} \cdot \mathrm{ha}^{-1}$ depending on the sowing method failed to show any further increase. The comparison of the function parameter revealed that the sowing method only influenced the level of the yield plateau ranging between $4.23 \mathrm{t} \cdot \mathrm{ha}^{-1}$ if sown in the third week of September (SD 4) and $5.56 \mathrm{t}^{\mathrm{h}} \mathrm{ha}^{-1}$ at the third week of August (SD 2). In contrast, the N application rate at the intersection of the linear model and the plateau yield (Nopt), as well as the linear slope, remained unaffected (Table 2) indicating that the sowing method (SD) by spring $\mathrm{N}$ interaction was not significant.

A similar pattern occurred when comparing spring $\mathrm{N}$ effects at different autumn $\mathrm{N}$ levels (Figure 1b; for estimated model parameters, see Table 2). Applying $\mathrm{N}$ in autumn increased the plateau yield from $4.48 \mathrm{t} \cdot \mathrm{ha}^{-1}$ in the unfertilized control up to $5.12,5.20$, and $5.32 \mathrm{t} \cdot \mathrm{ha}^{-1}$ in the 30, 60, and $90 \mathrm{~kg} \cdot \mathrm{N} \cdot \mathrm{ha}^{-1}$ treatment, respectively, but did not affect Nopt and slope (Table 2). No significant interactions between both $\mathrm{N}$ application dates occurred. 


\subsection{N Offtake by the Seeds}

Considering the $\mathrm{N}$ offtake by the seeds revealed similar results as observed for seed yield. Delaying sowing reduced $\mathrm{N}$ offtake ranging between $112 \mathrm{~kg} \cdot \mathrm{N} \cdot \mathrm{ha}^{-1}$ sown at the latest date and $141 \mathrm{~kg} \cdot \mathrm{N} \cdot \mathrm{ha}^{-1}$, if crop establishment was made in the third week of August. The additional $30 \mathrm{~kg} \cdot \mathrm{N} \cdot \mathrm{ha}^{-1}$ applied in autumn increased $\mathrm{N}$ offtake by $9 \mathrm{~kg} \cdot \mathrm{N} \cdot \mathrm{ha}^{-1}$, thus leaving $21 \mathrm{~kg} \cdot \mathrm{N} \cdot \mathrm{ha}{ }^{-1}$ ( $=70 \%$ of the applied $\mathrm{N}$ amount) in the system (Table 3). A further increase in the autumn $\mathrm{N}$ supply up to 60 and $90 \mathrm{~kg} \cdot \mathrm{N} \cdot \mathrm{ha}^{-1}$ increased $\mathrm{N}$ offtake by 14 and $18 \mathrm{~kg} \cdot \mathrm{N} \cdot \mathrm{ha}^{-1}$, thus boosting the $\mathrm{N}$ surplus by $46(=77 \%)$ and $72 \mathrm{~kg} \cdot \mathrm{N} \cdot \mathrm{ha}^{-1}(=80 \%)$, respectively. Again, no significant interactions could be identified.
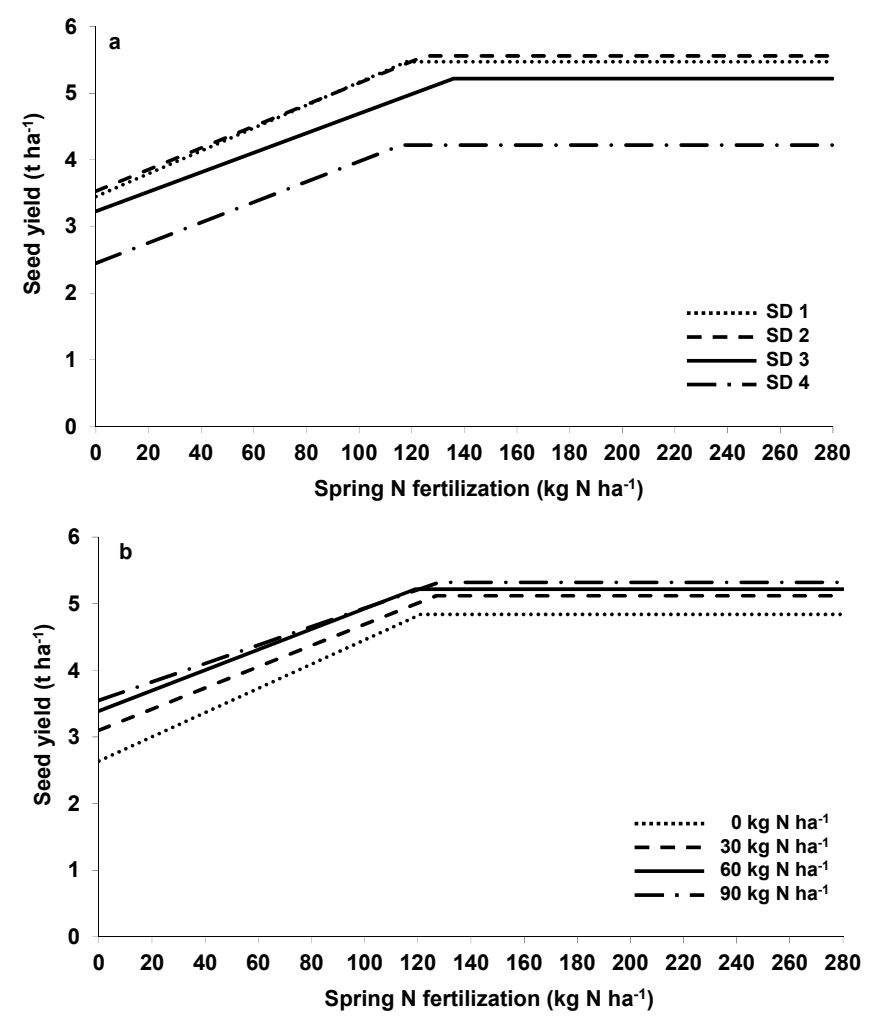

Figure 1. Effect of sowing method (SD) by spring $\mathrm{N}$ fertilization interaction (a) and autumn $\mathrm{N}$ by spring N fertilization (b) on seed yield of oilseed rape (2010, 2011, 2013; for function parameters, see Table 2). (SD 1-first week of August; S—third week of August; S-first week of September; S-third week of September).

Table 2. Estimated model parameters of the linear-plateau functions quantifying the relationship between spring $\mathrm{N}$ fertilization $\left(\mathrm{kg} \cdot \mathrm{N} \cdot \mathrm{ha}^{-1}\right)$ and seed yield $\left(\mathrm{t} \cdot \mathrm{ha}^{-1}\right)$ or $\mathrm{N}$ offtake with the seeds $\left(\mathrm{kg} \cdot \mathrm{N} \cdot \mathrm{ha}^{-1}\right)$ and between $\mathrm{N}$ uptake at the end of autumn growth and seed yield (t.ha $\left.{ }^{-1}\right)(2009 / 2010$, 2010/2011, 2012/2013).

\begin{tabular}{|c|c|c|c|c|c|c|c|c|}
\hline $\begin{array}{l}\text { Sowing } \\
\text { Method \& }\end{array}$ & $\begin{array}{c}\text { Autumn N } \\
\left(\mathrm{kg} \cdot \mathrm{N} \cdot \mathrm{ha}^{-1}\right)\end{array}$ & $\underset{\left(\mathrm{kg} \cdot \mathrm{N} \cdot \mathrm{ha}^{-1}\right)}{\text { Spring N }}$ & $n$ & $R^{2}$ & $p$ & Plateau $^{\dagger}$ & Nopt $\ddagger$ & Slope \\
\hline \multicolumn{9}{|c|}{ Seed yield (Figure 1a) } \\
\hline SD 1 & & & 240 & 0.65 & $<0.0001$ & $5.47^{\mathrm{a}, \mathrm{b} \$}$ & $117.7^{\mathrm{ns}}$ & $0.0172 \mathrm{~ns}$ \\
\hline SD 2 & & & 239 & 0.66 & $<0.0001$ & $5.56^{\mathrm{a}}$ & $125.2^{\mathrm{ns}}$ & $0.0162^{\mathrm{ns}}$ \\
\hline SD 3 & & & 240 & 0.49 & $<0.0001$ & $5.22^{b}$ & $136.2^{\mathrm{ns}}$ & $0.0147^{\mathrm{ns}}$ \\
\hline SD 4 & & & 240 & 0.27 & $<0.0001$ & $4.23^{c}$ & $116.4^{\mathrm{ns}}$ & $0.0153^{\mathrm{ns}}$ \\
\hline
\end{tabular}


Table 2. Cont.

\begin{tabular}{|c|c|c|c|c|c|c|c|c|}
\hline $\begin{array}{l}\text { Sowing } \\
\text { Method } \$\end{array}$ & $\begin{array}{c}\text { Autumn N } \\
\left(\mathrm{kg} \cdot \mathrm{N} \cdot \mathrm{ha}^{-1}\right)\end{array}$ & $\underset{\left(\mathrm{kg} \cdot \mathrm{N} \cdot \mathrm{ha}^{-1}\right)}{\text { Spring N }}$ & $n$ & $R^{2}$ & $p$ & Plateau $^{\dagger}$ & Nopt $\ddagger$ & Slope \\
\hline \multicolumn{9}{|c|}{ Seed yield (Figure 1b) } \\
\hline \multicolumn{3}{|c|}{0} & 240 & 0.41 & $<0.0001$ & $4.48^{b}$ & $121.4^{\mathrm{ns}}$ & $0.0185^{\mathrm{ns}}$ \\
\hline \multicolumn{3}{|c|}{30} & 240 & 0.44 & $<0.0001$ & $5.12^{\mathrm{a}}$ & $127.3^{\mathrm{ns}}$ & $0.0159^{\mathrm{ns}}$ \\
\hline \multicolumn{3}{|c|}{60} & 239 & 0.39 & $<0.0001$ & $5.20^{\mathrm{a}}$ & $119.1^{\mathrm{ns}}$ & $0.0152^{\mathrm{ns}}$ \\
\hline \multicolumn{3}{|c|}{90} & 240 & 0.41 & $<0.0001$ & $5.32^{\mathrm{a}}$ & $127.7^{\mathrm{ns}}$ & $0.0138^{\mathrm{ns}}$ \\
\hline \multicolumn{9}{|c|}{$\mathrm{N}$ offtake by the seeds (Figure 2a) } \\
\hline \multicolumn{3}{|l|}{ SD 1} & 240 & 0.73 & $<0.0001$ & $162.8^{b}$ & $156.5^{\mathrm{ns}}$ & $0.5344^{\mathrm{a}}$ \\
\hline \multicolumn{3}{|l|}{ SD 2} & 239 & 0.75 & $<0.0001$ & $171.1^{\mathrm{a}}$ & $195.3^{\mathrm{ns}}$ & $0.4360^{b}$ \\
\hline \multicolumn{3}{|l|}{ SD 3} & 240 & 0.65 & $<0.0001$ & $159.6^{\mathrm{b}}$ & $182.2^{\mathrm{ns}}$ & $0.4257^{b}$ \\
\hline \multicolumn{3}{|l|}{ SD 4} & 240 & 0.39 & $<0.0001$ & $131.3^{c}$ & $176.1^{\mathrm{ns}}$ & $0.3428^{c}$ \\
\hline \multicolumn{9}{|c|}{$\mathrm{N}$ offtake by the seeds (Figure $2 \mathrm{~b}$ ) } \\
\hline \multicolumn{3}{|c|}{0} & 240 & 0.56 & $<0.0001$ & $148.5^{\mathrm{b}}$ & $181.4^{\mathrm{ns}}$ & $0.4568^{\mathrm{ns}}$ \\
\hline \multicolumn{3}{|c|}{30} & 240 & 0.62 & $<0.0001$ & $157.7^{\mathrm{a}}$ & $190.4^{\mathrm{ns}}$ & $0.4189 \mathrm{~ns}$ \\
\hline \multicolumn{3}{|c|}{60} & 239 & 0.56 & $<0.0001$ & $158.3^{\mathrm{a}}$ & $177.2^{\mathrm{ns}}$ & $0.4056^{\mathrm{ns}}$ \\
\hline \multicolumn{3}{|c|}{90} & 240 & 0.63 & $<0.0001$ & $164.6^{\mathrm{a}}$ & $190.8^{\mathrm{ns}}$ & $0.3909^{\mathrm{ns}}$ \\
\hline \multicolumn{9}{|c|}{ Seed yield (Figure 4) } \\
\hline & & 0 & 190 & 0.42 & $<0.0001$ & $3.99^{c}$ & $64.9^{\mathrm{a}}$ & $0.0245^{c}$ \\
\hline & & 80 & 190 & 0.41 & $<0.0001$ & $4.80^{\mathrm{b}}$ & $13.1^{\mathrm{b}}$ & $0.1329^{b}$ \\
\hline & & 160 & 192 & 0.44 & $<0.0001$ & $5.40^{\mathrm{a}}$ & $6.8^{c}$ & $0.3487^{\mathrm{a}}$ \\
\hline & & 240 & 191 & 0.43 & $<0.0001$ & $5.47^{\mathrm{a}}$ & $6.7^{c}$ & $0.3697^{\mathrm{a}}$ \\
\hline & & 280 & 191 & 0.42 & $<0.0001$ & $5.52^{\mathrm{a}}$ & $6.4^{c}$ & $0.4319^{a}$ \\
\hline
\end{tabular}

${ }^{+}$-Plateau-plateau yield and $\mathrm{N}$ offtake, respectively. ${ }^{\ddagger} \mathrm{Nopt}-\mathrm{N}$ application rate $\left(\mathrm{kg} \cdot \mathrm{N} \cdot \mathrm{ha}^{-1}\right)$ and $\mathrm{N}$ uptake at the end of autumn growth, respectively, at the intersection of the linear model and the plateau (i.e., minimum $\mathrm{N}$ amount required to achieve maximum yield). \$_SD 1-first week of August; SD 2-third week of August; SD 3-first week of September; SD 4-third week of September. ${ }^{\$}$-Different letters indicate significant differences within one parameter and one factor at $p=0.05$; ns-not significant at $p=0.05$.

Table 3. Sowing method by autumn $\mathrm{N}$ application interaction effects on $\mathrm{N}$ offtake by WOSR seed yield $\left(\mathrm{kg} \cdot \mathrm{N} \cdot \mathrm{ha}^{-1}\right.$ ) (based on average of 2009/2010, 2010/2011, 2012/2013 and all spring treatments).

\begin{tabular}{|c|c|c|c|c|c|}
\hline \multirow[b]{2}{*}{ Sowing Method $\S$} & \multicolumn{4}{|c|}{ Autumn N Application $\left(\mathrm{kg} \cdot \mathrm{N} \cdot \mathrm{ha}^{-1}\right)$} & \multirow[b]{2}{*}{ Mean } \\
\hline & 0 & 30 & 60 & 90 & \\
\hline SD 1 & 133 & 156 & 140 & 143 & $138^{a, b, t}$ \\
\hline SD 2 & 134 & 138 & 145 & 146 & $141^{\mathrm{a}}$ \\
\hline SD 3 & 116 & 136 & 140 & 143 & $133^{b}$ \\
\hline $\mathrm{SD} 4$ & 100 & 110 & 114 & 123 & $112^{c}$ \\
\hline Mean & $121^{\mathrm{c}}$ & $130^{b}$ & $135^{\mathrm{a}, \mathrm{b}}$ & $139^{a}$ & \\
\hline
\end{tabular}

\$_SD 1-first week of August; SD 2—third week of August; SD 3-first week of September; SD 4-third week of September. ${ }^{\dagger}-$ Different letters indicate significant differences within a factor at $p=0.05$. The sowing method by autumn $\mathrm{N}$ interaction was significant at $p=0.05$.

Since spring $\mathrm{N}$ fertilization increased not only seed yield, but also seed $\mathrm{N}$ concentration (data not shown), the $\mathrm{N}$ rate required to achieve maximum yield (Nopt) was higher for $\mathrm{N}$ offtake (160-195 kg.N.ha ${ }^{-1}$ ) than for seed yield (about 116-136 kg.N.ha ${ }^{-1}$ ) (Figure 2a; for estimated model parameters, see Table 2) at all sowing methods. In addition, the linear slope decreased with delayed sowing.

In combination with spring $\mathrm{N}$, autumn $\mathrm{N}$ application was positively correlated with only the level of the plateau ranging between 149 and $166 \mathrm{~kg} \cdot \mathrm{N} \cdot \mathrm{ha}^{-1}$ (Figure $2 \mathrm{~b}$; for estimated model parameters, see Table 2), while Nopt and the slope were similar. Autumn $\mathrm{N}$ did not affect seed N concentration; in consequence, increased $\mathrm{N}$ offtake was mainly due to higher seed yields. 

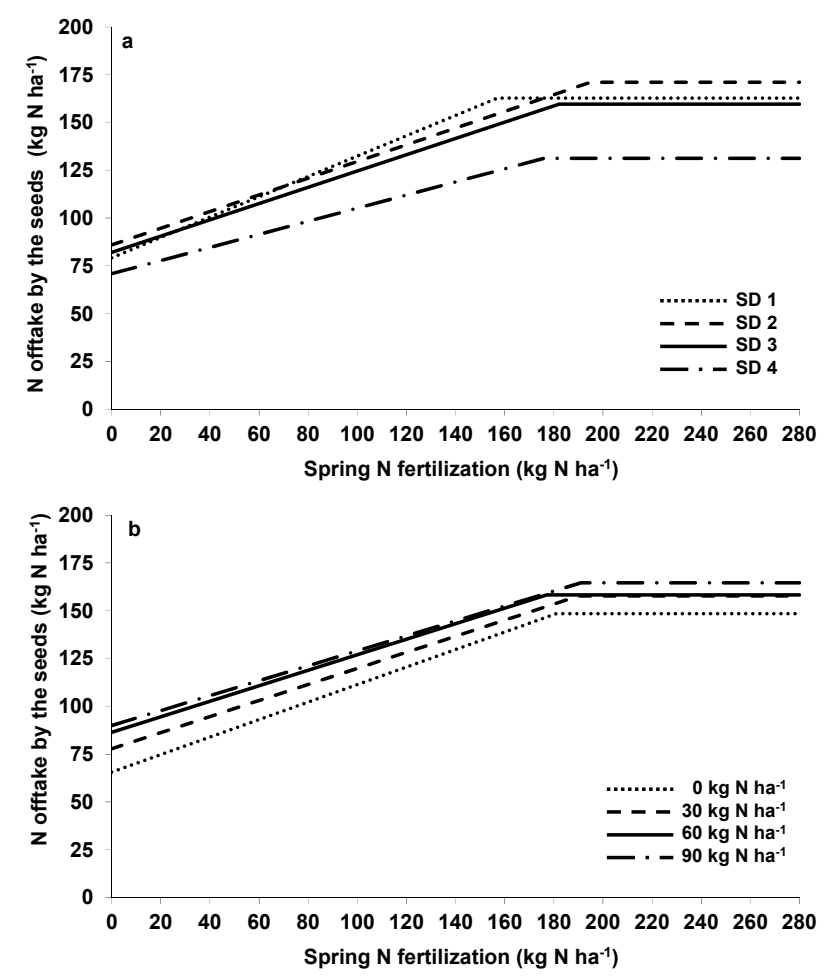

Figure 2. Effect of sowing method (SD) by spring $\mathrm{N}$ fertilization interaction (a) and autumn $\mathrm{N}$ by spring N fertilization (b) on N offtake by the seeds of oilseed rape (2010, 2011, 2013; for function parameters, see Table 2). (SD 1-first week of August; SD 2-third week of August; SD 3-first week of September; SD 4-third week of September).

\subsection{Seed Oil Concentration and Oil Yield}

Seed oil concentration was highest at early sowing and fell if sowing was delayed (Figure 3). Likewise, spring $\mathrm{N}$ significantly decreased oil concentration while autumn $\mathrm{N}$ had no effects. The slope was steepest if plant establishment occurred in August. In consequence, oil yield showed a similar pattern as seed yield with significant effects of sowing method $\left(2.17,2.19,2.03\right.$, and $1.61 \mathrm{t} \cdot \mathrm{ha}^{-1}$ in SD 1, SD 2, SD 3, and SD 4, respectively), autumn N $\left(1.84,1.99,2.06\right.$, and $2.10 \mathrm{t} \cdot \mathrm{ha}^{-1}$ in the $0,30,60$, and $90 \mathrm{~kg} \cdot \mathrm{N} \cdot \mathrm{ha}^{-1}$ treatment, respectively) and spring $\mathrm{N}$ application $\left(1.44,1.99,2.20,2.18\right.$, and $2.18 \mathrm{t} \cdot \mathrm{ha}^{-1}$ in the $0,80,160,240$, and $280 \mathrm{~kg} \cdot \mathrm{N} \cdot \mathrm{ha}^{-1}$ treatment, respectively). No significant interactions were observed.

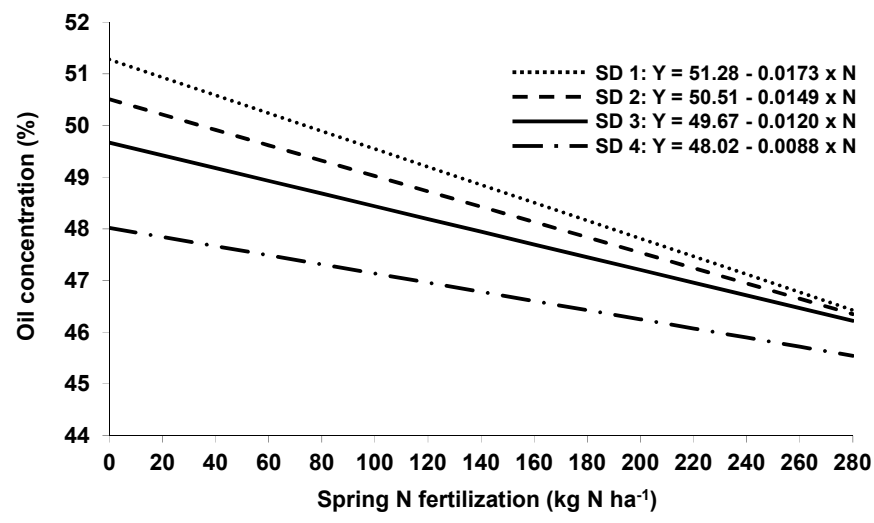

Figure 3. Effect of sowing method (SD) by spring $N$ fertilization interaction on seed oil concentration of the seeds of oilseed rape (2010, 2011, 2013). (SD 1-first week of August; SD 2-third week of August; SD 3-first week of September; SD 4-third week of September). 


\subsection{Apparent N Use Efficiency}

The apparent $\mathrm{N}$ use efficiency (NUE) describes the additional $\mathrm{N}$ offtake by the seeds due to the fertilization in relation to the respective $\mathrm{N}$ supply. Since no significant interaction between autumn and spring $\mathrm{N}$ application occurred, NUE of autumn $\mathrm{N}$ was presented based on the average of the spring $\mathrm{N}$ treatments and vice versa (Table 4). NUE of autumn $\mathrm{N}$ supply decreased with increasing $\mathrm{N}$ amount from $25 \%$ in the $30 \mathrm{~kg} \cdot \mathrm{N} \cdot \mathrm{ha}^{-1}$ treatment down to $20 \%$ in the plots which had received $90 \mathrm{~kg} \cdot \mathrm{N} \cdot \mathrm{ha}^{-1}$; however, this reduction was not significant at $p=0.05$. The date of plant establishment significantly affected NUE, being lowest at SD 1 (11\%) and highest at SD $3(38 \%)$. In contrast, the early sown plots utilized spring applied $\mathrm{N}$ to a larger extent than the later sown ones (Table 4). Increasing spring $\mathrm{N}$ application significantly reduced the respective NUE from $46 \%\left(80 \mathrm{~kg} \cdot \mathrm{N} \cdot \mathrm{ha}^{-1}\right)$ to $28 \%\left(280 \mathrm{~kg} \cdot \mathrm{N} \cdot \mathrm{ha}{ }^{-1}\right)$. The sowing method by autumn $\mathrm{N}$ interaction and the sowing method by spring $\mathrm{N}$ interaction were not significant $(p>0.05)$.

Table 4. Sowing method by $\mathrm{N}$ application interaction effects on apparent $\mathrm{N}$ use efficiency (\%) $(2009 / 2010,2010 / 2011,2012 / 2013)$.

\begin{tabular}{|c|c|c|c|c|c|}
\hline \multicolumn{6}{|c|}{ Sowing Method $\S$} \\
\hline & SD 1 & SD 2 & SD 3 & SD 4 & Mean \\
\hline \multicolumn{6}{|c|}{ Autumn $\mathrm{N}$ application $\left(\mathrm{kg} \cdot \mathrm{N} \cdot \mathrm{ha}^{-1}\right)$} \\
\hline 0 & - & - & - & - & - \\
\hline 30 & 8.4 & 13.0 & 44.4 & 32.6 & $24.6^{\mathrm{ns}, \mathrm{t}}$ \\
\hline 60 & 14.0 & 18.5 & 40.0 & 22.5 & $23.7^{\mathrm{ns}}$ \\
\hline 90 & 11.1 & 13.2 & 30.3 & 25.0 & $19.9^{\mathrm{ns}}$ \\
\hline Mean & $11.1^{\mathrm{c}}$ & $14.9^{\mathrm{c}}$ & $38.2^{\mathrm{a}}$ & $26.7^{b}$ & \\
\hline \multicolumn{6}{|c|}{ Spring $\mathrm{N}$ application $\left(\mathrm{kg} \cdot \mathrm{N} \cdot \mathrm{ha}^{-1}\right)$} \\
\hline 0 & - & - & - & - & - \\
\hline 80 & 53.1 & 47.8 & 41.3 & 41.9 & $46.0^{\mathrm{a}}$ \\
\hline 160 & 47.0 & 43.6 & 42.6 & 34.3 & $41.9^{\mathrm{a}}$ \\
\hline 240 & 35.9 & 35.1 & 31.6 & 26.2 & $32.2^{b, c}$ \\
\hline 280 & 31.9 & 31.5 & 28.1 & 22.1 & $28.4^{\mathrm{c}}$ \\
\hline Mean & $42.0^{\mathrm{a}}$ & $39.5^{\mathrm{a}, \mathrm{b}}$ & $35.9^{b}$ & $31.1^{\mathrm{c}}$ & \\
\hline
\end{tabular}

S_SD 1 - first week of August; SD 2—third week of August; SD 3—first week of September; SD 4-third week of September. ${ }^{+}-\mathrm{ns}-$ not significant $(p>0.05)$. Different letters indicate significant differences within one parameter and one factor at $p=0.05$. The sowing method by autumn $\mathrm{N}$ interaction and the sowing method by spring $\mathrm{N}$ interaction were not significant $(p>0.05)$.

\subsection{Relation between Above-Ground N Uptake in Autumn and Seed Yield}

The combination of four sowing methods and four autumn $\mathrm{N}$ treatments resulted in 16 different WOSR canopies before winter. The estimation of the $\mathrm{N}$ uptake at the end of autumn growth allowed to determine the least required $\mathrm{N}$ application needed for optimal seed yield. Presuming a Linear-Plateau approach for each spring $\mathrm{N}$ treatment separately, the minimum autumn $\mathrm{N}$ uptake depended on the amount of spring $\mathrm{N}$ fertilization (Figure 4). A comparison of the estimated model parameters (Table 4) revealed similar curves if spring $\mathrm{N}$ supply was at least $160 \mathrm{~kg} \cdot \mathrm{N} \cdot \mathrm{ha}{ }^{-1}$. In this case, WOSR canopies should have taken up at least about $7 \mathrm{~kg} \cdot \mathrm{N} \cdot \mathrm{ha} \mathrm{a}^{-1}$ to achieve maximum seed yield. In contrast, canopies without spring $\mathrm{N}$ supply required $65 \mathrm{~kg} \cdot \mathrm{N} \cdot \mathrm{ha} \mathrm{a}^{-1}$ accumulated in the above-ground biomass. Larger canopies did not result in higher seed yield. 


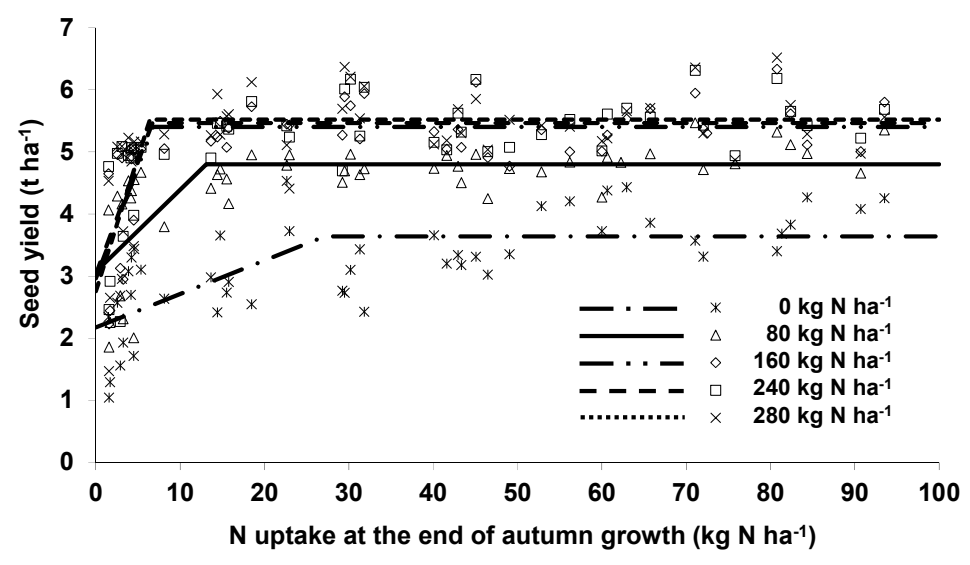

Figure 4. Relationship between $\mathrm{N}$ uptake of oilseed rape at the end of autumn growth and seed yield at different spring $\mathrm{N}$ fertilization levels (2010, 2011, 2013; for function parameters see Table 2).

\section{Discussion}

The experimental design allowed for an investigation of the effects of sowing method, autumn $\mathrm{N}$, and spring $\mathrm{N}$ supply, as well as their interactions, on yield and $\mathrm{N}$ offtake by the seeds of WSOR. Due to varying sowing methods and autumn $\mathrm{N}$ supplies, 16 different WOSR canopies were established in autumn, each combined with increasing spring $\mathrm{N}$ fertilization in order to estimate $\mathrm{N}$ response curves separately for each canopy. The results confirmed the current recommendation that under the climatic conditions of northern Europe WOSR should ideally be sown between the middle and end of August, whereas plant establishment after mid-September clearly decreased seed yield, which was in agreement with [7]. It should be noted that, if the weather conditions in the following spring are favorable, even an WOSR crop sown in the third week of September with two to four leaves at the end of autumn growth was able to achieve more than $5 \mathrm{t} \cdot \mathrm{ha}^{-1}$ [29]; however, since long-term weather forecasts are not yet available, the risk of yield penalties increases with shifting WOSR sowing to the end of September.

In combination with late sowing, farmers often apply additional $\mathrm{N}$ in autumn to ensure adequate WOSR growth before winter. No significant interaction between the sowing method and autumn as well as spring $\mathrm{N}$ fertilization on seed yield could be observed in our experiments (Table 1). Applying at least $30 \mathrm{~kg} \cdot \mathrm{N} \cdot \mathrm{ha}^{-1}$ in autumn increased WOSR yield at all sowing methods averaged over three years, although unfertilized WOSR canopies established in August already accumulated about $100 \mathrm{~g} \cdot \mathrm{DM} \cdot \mathrm{m}^{-2}$ and $34 \mathrm{~kg} \cdot \mathrm{N} \cdot \mathrm{ha}^{-1}$ at the end of autumn growth compared to $3 \mathrm{~g} \cdot \mathrm{DM} \cdot \mathrm{m}^{-2}$ and $<2 \mathrm{~kg} \cdot \mathrm{N} \cdot \mathrm{ha}^{-1}$ in the late sown ones [29]. In addition, the $\mathrm{N}$ amount in early sown canopies clearly exceeded the threshold for optimal autumn $\mathrm{N}$ uptake, as shown in Figure 4. However, the pathway(s) which allowed autumn $\mathrm{N}$ to significantly increase seed yield for the early sowing method treatment require(s) further study. On the one hand, it can be argued that despite the often relatively small $\mathrm{N}$ uptake before winter, the additional $\mathrm{N}$ supply in autumn enables the plants to better utilize $(\mathrm{N})$ resources in spring, thus indicating a physiological pathway. On the other hand, autumn $\mathrm{N}$ might act as advanced spring $\mathrm{N}$ fertilization if $\mathrm{N}$ is not leached out of the potential rooting zone during winter. In this case, an interaction between autumn and spring $\mathrm{N}$ treatments should be expected; however, it was not observed in our experiments (Figure 1b, Figure 2b, and Table 2). In contrast, Henke et al. [19] provided an approach which took autumn $\mathrm{N}$ uptake into account when estimating spring $\mathrm{N}$ fertilization, thus assuming an autumn $\mathrm{N}$ by spring $\mathrm{N}$ interaction. The authors suggested reducing the spring $\mathrm{N}$ amount if $\mathrm{N}$ in the canopy exceeds $50 \mathrm{~kg} \cdot \mathrm{N} \cdot \mathrm{ha}^{-1}$ at the end of autumn growth. With only small increases in $\mathrm{N}$ offtake by the seeds (Table 3) and the resulting small NUE (Table 4) in mind, autumn $\mathrm{N}$ should not exceed $30 \mathrm{~kg} \cdot \mathrm{N} \cdot \mathrm{ha}^{-1}$.

In order to describe the N effects, a "Linear Response and Plateau" approach (LRP) was chosen, since using quadratic $\mathrm{N}$ response curves resulted in quite high $\mathrm{N}$ amounts required to achieve yield 
maximum due to a less steep slope compared to wheat [30,31]. Although the quadratic approach seems to be safer in terms of preventing financial losses under conditions of uncertainty, the risk of high positive $\mathrm{N}$ balances rises and the introduction of penalty functions may therefore favor the LPR model, especially against the background of high $\mathrm{N}$ surpluses in WOSR growing systems [31].

Based on the LRP approach, the minimum amount of spring $\mathrm{N}$ required for maximum seed yield ranged, based on average of the three experimental years, between 120 and $140 \mathrm{~kg} \cdot \mathrm{N} \cdot \mathrm{ha}^{-1}$, regardless of the sowing method and the autumn $\mathrm{N}$ supply, which was lower than local recommendation according to the "Düngeverordnung" [32], the national implementation of the EU Nitrate Directive, as well as results from other authors [26,33]. Since $\mathrm{N}$ fertilization also increased seed $\mathrm{N}$ concentration, optimal $\mathrm{N}$ supply for the maximum $\mathrm{N}$ offtake by the seeds was higher (about $180-190 \mathrm{~kg} \cdot \mathrm{N} \cdot \mathrm{ha}{ }^{-1}$, Figure 2a,b and Table 2). In addition, delayed sowing methods also led to a higher seed $\mathrm{N}$ concentration, whereas autumn $\mathrm{N}$ had no effects [29].

$\mathrm{N}$-use efficiency (NUE) for autumn (spring) $\mathrm{N}$ was calculated by comparing the seed yield according to the average of the spring (autumn) $\mathrm{N}$ treatments in relation to the amount of applied $\mathrm{N}$ in autumn (spring). In general, NUE of WOSR is lower compared to wheat or barley [23,30,34], which often has been associated with a low foliar $\mathrm{N}$ remobilization, thus with a high $\mathrm{N}$ concentration in WOSR leaves dropping off during the growth period, especially after flowering [35-37]. NUE decreased with increasing $\mathrm{N}$ amounts (Table 4). WOSR utilized autumn $\mathrm{N}$ to a lower extent than spring applied $\mathrm{N}[9,11]$. Autumn NUE was highest when WOSR was sown in the first week of September, which was mainly due to the lower $\mathrm{N}$ offtake of the unfertilized plots compared to earlier sowing, while the autumn $\mathrm{N}$ fertilized ones showed similar values (Table 3). Therefore, NUE alone is not suitable for evaluating the sustainability of a cropping system as the $\mathrm{N}$ offtake and, in consequence, the $\mathrm{N}$ balance ( $\mathrm{N}$ surplus) have to be taken into account. From an environmental point of view, $\mathrm{N}$ application in autumn, if any, should not exceed $30 \mathrm{~kg} \cdot \mathrm{N} \cdot \mathrm{ha}^{-1}$, since most of the $\mathrm{N}$ remained in the system, increasing the risk of losses in the subsequent crops [27]. According to the presented results using the LPR approach, applying $120-130 \mathrm{~kg} \cdot \mathrm{N} \cdot \mathrm{ha}^{-1}$ in spring were sufficient to achieve the highest seed yields. However, using quadratic $\mathrm{N}$ response curves, $180-200 \mathrm{~kg} \cdot \mathrm{N} \cdot \mathrm{ha}{ }^{-1}$ were required to get the economic optimal seed yield [29], representing an application rate that was similar to that used by the farmers.

The estimation of the minimum amount of $\mathrm{N}$ taken up by the canopy at the end of autumn in order to achieve maximum seed yield was based on the LPR approach, where only the spring N fertilization was additionally considered. Including autumn $\mathrm{N}$ supply did not improve the relationship (except if the canopy remained unfertilized in spring), indicating that the above-ground $\mathrm{N}$ accumulation at the end of autumn growth adequately covered the effects of autumn $\mathrm{N}$ application. Optimal autumn $\mathrm{N}$ uptake depended on the amount of spring $\mathrm{N}$. If there are plans for $160 \mathrm{~kg} \cdot \mathrm{N} \cdot \mathrm{ha}{ }^{-1}$ or more to be applied in spring, an $\mathrm{N}$ uptake of $10 \mathrm{~kg} \cdot \mathrm{N} \cdot \mathrm{ha}^{-1}$ before winter should enable the canopies to produce optimal seed yield. Even under the less favorable conditions occurring in autumn 2010, $13 \mathrm{~kg} \cdot \mathrm{N} \cdot \mathrm{ha}^{-1}$ seemed to be sufficient [29]. Assuming a quadratic relationship, about $40 \mathrm{~kg} \cdot \mathrm{N} \cdot \mathrm{ha}{ }^{-1}$ were required to achieve $95 \%$ of the yield maximum [29] being similar to the $50 \mathrm{~kg} \cdot \mathrm{N} \cdot \mathrm{ha}^{-1}$ suggested by Henke et al. [19] to represent an average rapeseed canopy which will be fertilized in spring according to the official recommendation. However, a threshold of $1 \mathrm{~g}$ single plant DM for minimum autumn growth which is often used by the farmers results in about $20 \mathrm{~kg} \cdot \mathrm{N} \cdot \mathrm{ha}^{-1}$ assuming 40 plants $\cdot \mathrm{m}^{-2}$ and $5 \% \mathrm{~N}$ concentration in the above-ground biomass.

\section{Materials and Methods}

\subsection{Site and Soil}

The field experiment was carried out on a pseudogleyic sandy loam (Luvisol: $100 \mathrm{~g} \cdot \mathrm{kg}^{-1}$ clay, $\mathrm{pH}$ 6.6, $86 \mathrm{mg} \cdot \mathrm{kg}^{-1} \mathrm{P}, 79 \mathrm{mg} \cdot \mathrm{kg}^{-1} \mathrm{~K}, 150 \mathrm{~g} \cdot \mathrm{kg}^{-1} \mathrm{Mg}, 13.8 \mathrm{~g} \cdot \mathrm{kg}^{-1} \mathrm{C}_{\text {org }}, 1.1 \mathrm{~g} \cdot \mathrm{kg}^{-1} \mathrm{~N}_{\text {org }}$ ) at the Hohenschulen Experimental Farm $\left(10.0^{\circ} \mathrm{E}, 54.3^{\circ} \mathrm{N}, 30 \mathrm{~m}\right.$ above see level) of the Kiel University, located in northern Germany $15 \mathrm{~km}$ west of Kiel (Schleswig-Holstein). 
The climate of NW Germany can be described as humid. Total annual rainfall averages $750 \mathrm{~mm}$ at the experimental site, with ca. $400 \mathrm{~mm}$ received during April-September, the main growing season, and ca. $350 \mathrm{~mm}$ during October-March. In all three years, the mean air temperature in October was below the long-term average. Especially in autumn 2010, the low temperature in August until November, in combination with very high rainfall in August and September, resulted in poor autumn growth in all treatments (Table 5).

Table 5. Monthly rainfall $(\mathrm{mm})$ and mean air temperature $\left({ }^{\circ} \mathrm{C}\right)$ at Hohenschulen, Germany.

\begin{tabular}{ccccccccc}
\hline \multicolumn{3}{c}{ Total Rainfall $(\mathbf{m m})$} & \multicolumn{5}{c}{ Mean Air Temperature $\left({ }^{\circ} \mathbf{C}\right)$} \\
\hline & $\mathbf{2 0 0 9 / 2 0 1 0}$ & $\mathbf{2 0 1 0 / 2 0 1 1}$ & $\mathbf{2 0 1 2 / 2 0 1 3}$ & $\begin{array}{c}\text { Long-Term } \\
\text { Mean }\end{array}$ & $\mathbf{2 0 0 9 / 2 0 1 0}$ & $\mathbf{2 0 1 0 / 2 0 1 1}$ & $\mathbf{2 0 1 2 / 2 0 1 3}$ & $\begin{array}{c}\text { Long-Term } \\
\text { Mean }\end{array}$ \\
\hline August & 69 & 105 & 56 & 59 & 17.8 & 16.1 & 16.7 & 17.9 \\
September & 28 & 123 & 59 & 61 & 14.3 & 12.6 & 12.7 & 14.2 \\
October & 63 & 55 & 71 & 75 & 7.7 & 8.7 & 8.6 & 9.8 \\
November & 109 & 113 & 39 & 58 & 7.3 & 3.8 & 5.1 & 4.9 \\
December & 49 & 29 & 72 & 62 & 0.2 & -4.6 & 0.0 & 1.6 \\
January & 21 & 37 & 68 & 48 & -4.1 & 0.4 & 0.5 & 1.2 \\
February & 43 & 39 & 24 & 50 & -1.7 & -0.1 & -0.7 & 2.0 \\
March & 56 & 19 & 22 & 44 & 3.6 & 3.2 & -1.1 & 3.4 \\
April & 17 & 3 & 18 & 44 & 7.5 & 10.4 & 6.1 & 8.0 \\
May & 50 & 36 & 141 & 62 & 8.8 & 12.2 & 11.4 & 11.9 \\
June & 50 & 93 & 100 & 69 & 14.3 & 15.2 & 13.9 & 14.8 \\
July & 24 & 150 & 40 & 100 & 19.5 & 15.7 & 17.6 & 16.9 \\
\hline
\end{tabular}

\subsection{Treatments}

In 2009/2010, 2010/2011, and 2012/2013, a field experiment with winter oilseed rape (WOSR) cv. Visby was established to test the effects of sowing method (SD) and $\mathrm{N}$ application in autumn and spring on crop growth in autumn, seed yield, and plant N recovery. Heavy rainfall in August 2011 prevented a proper crop establishment, therefore, no oilseed rape was grown in that year. In order to create sufficiently differentiated canopies, the four sowing dates ranged between the first week of August and the third week of September (Table 6). The seed density was increased with delaying the sowing dates resulting in $35,40,50$, and 70 seeds $\cdot \mathrm{m}^{-2}$, respectively, according to common farmers' practice. Since sowing date was confounded by seed rate, the term 'sowing method' is used throughout the paper. In addition, each sowing method received four autumn $\mathrm{N}$ treatments $\left(0,30,60\right.$, and $90 \mathrm{~kg} \cdot \mathrm{N} \cdot \mathrm{ha}{ }^{-1}$ as calcium ammonium nitrate with $27 \% \mathrm{~N}$; for application dates, see Table 6), resulting in 16 sowing method by $\mathrm{N}$ supply combinations. Each of these 16 different canopies was fertilized with five $\mathrm{N}$ amounts $\left(0 / 0,40 / 40,80 / 80,120 / 120\right.$, and $140 / 140 \mathrm{~kg} \cdot \mathrm{N} \cdot \mathrm{ha}^{-1}$ as calcium ammonium nitrate with $27 \% \mathrm{~N}$ ) in spring in order to estimate separate $\mathrm{N}$ response curves. $\mathrm{N}$ was applied in split-dressings at the beginning of spring growth and at stem elongation (for application dates, see Table 6).

Table 6. Dates of sowing, autumn, and spring $\mathrm{N}$ application of winter oilseed rape.

\begin{tabular}{ccccc}
\hline \multirow{2}{*}{ Sowing } & & \multicolumn{3}{c}{ Year } \\
\cline { 3 - 5 } & & $\mathbf{2 0 0 9 / 2 0 1 0}$ & $\mathbf{2 0 1 0 / 2 0 1 1}$ & $\mathbf{2 0 1 2 / 2 0 1 3}$ \\
\hline & SD 1 & 5 August & 12 August & 11 August \\
& SD 2 & 18 August & 28 August & 23 August \\
& SD 3 & 1 September & 7 September & 5 September \\
& SD 4 & 21 September & 21 September & 17 September \\
\hline \multirow{4}{*}{ N application in autumn } & SD 1 & 27 August & 24 August & 3 September \\
& SD 2 & 27 August & 8 September & 3 September \\
& SD 3 & 2 September & 8 September & 10 September \\
& SD 4 & 22 September & 30 September & 19 September \\
\hline First N application in spring & & 23 March & 3 March & 4 March \\
Second N application in spring & & 12 April & 8 April & 15 April \\
\hline
\end{tabular}


The sowing methods as main plots were randomized with four replicates, while the $\mathrm{N}$ treatments were randomized within the main plots. This experimental design allowed for analyzing the sowing method effects separately for each year. The single plot size was $3 \mathrm{~m} \times 12 \mathrm{~m}$. Winter barley was the preceding crop; its straw remained on the plots. In general, the plots were ploughed within one day before sowing. Crop management not involving the treatments (e.g., $\mathrm{P}$ and K supply, soil tillage, pesticide application) were applied according to local recommendations to achieve optimal yield.

\subsection{Measurements}

In all sowing methods plant samples were taken at the end of autumn growth. Plants were dug up from an area of $1 \mathrm{~m}^{2}$. After washing, above-ground biomass was analyzed for dry matter (DM) and $\mathrm{N}$ concentration using the near infrared spectroscopy (NIRS) analysis. Autumn N uptake was calculated by multiplying above-ground $\mathrm{DM}$ and the respective $\mathrm{N}$ concentration.

In order to minimize border effects, only a core of $1.75 \mathrm{~m} \times 6 \mathrm{~m}\left(=10.5 \mathrm{~m}^{2}\right)$ was combine harvested at maturity to determine seed yield (standardized to $t \cdot \mathrm{ha}^{-1}$ with $91 \%$ DM based on the moisture content of a seed subsample). Oil and $\mathrm{N}$ concentration of the seeds (at 100\% DM) were determined by NIRS. $\mathrm{N}$ offtake by the seeds results from the product of seed yield DM and $\mathrm{N}$ concentration.

Apparent $\mathrm{N}$ use efficiency (NUE) was defined as the difference between the $\mathrm{N}$ offtake by the seeds in the fertilized and unfertilized treatment in relation to the $\mathrm{N}$ amount. Since no interaction between autumn and spring $\mathrm{N}$ fertilization occurred, NUE of the autumn (spring) $\mathrm{N}$ application was calculated based on the average of the spring (autumn) $\mathrm{N}$ treatments.

\subsection{Statistical Analysis}

First, the effects of sowing methods (SD), autumn and spring $\mathrm{N}$ fertilization were analyzed using a mixed model approach (SAS 9.4, Proc MIXED, SAS Institute Inc., Cary, NC, US) with "year" and "replication" as random terms. Since the SD by autumn N by spring N interaction was not significant, only the interactions between two factors as average on the remaining factor are presented.

Second, the effects of spring $\mathrm{N}$ application on seed yield and $\mathrm{N}$ offtake by the seeds were estimated by using a "Linear-Plateau" approach (Proc NLIN) separately for the sowing methods and the autumn $\mathrm{N}$ treatments, respectively.

The 'Linear-Plateau' model is specified by three parameters $\mathrm{a}, \mathrm{b}$, and $\mathrm{P}$ as follows:

$$
\begin{gathered}
\mathrm{Y}=\mathrm{a}+\mathrm{bX}+\varepsilon \rightarrow \text { if } \mathrm{X}<\text { Nopt } \\
\mathrm{Y}=\mathrm{P}+\varepsilon \rightarrow \text { if } \mathrm{X} \geq \text { Nopt }
\end{gathered}
$$

where $\mathrm{Y}$ denotes the DM yield ( $\left.\mathrm{t} \cdot \mathrm{ha}{ }^{-1}\right)$ or the $\mathrm{N}$ offtake by the seeds $\left(\mathrm{kg} \cdot \mathrm{N} \cdot \mathrm{ha}{ }^{-1}\right), \mathrm{X}$ the application rate of $\mathrm{N}\left(\mathrm{kg} \cdot \mathrm{N} \cdot \mathrm{ha} \mathrm{a}^{-1}\right)$ or the $\mathrm{N}$ uptake in autumn, a the intercept, $\mathrm{b}$ the linear coefficient, and $\varepsilon$ the error term. Nopt is the nitrogen application rate at the intersection of the linear model and the plateau yield $\mathrm{P}$ (Table 2). Function parameters were compared by a modified t-test based on Zar [38].

Seed oil concentration was analyzed by performing an analysis of covariance (Proc GLM).

A $p$-value of 0.05 was considered to be significant in the statistical analyses.

\section{Conclusions}

The presented results confirmed that the sowing of WOSR in the third week of August until the first week of September as being the best sowing method in northern Germany. Even in canopies which were well developed before winter, autumn $\mathrm{N}$ application increased seed yield. However, although economically suitable, autumn $\mathrm{N}$ should be critically discussed from an environmental point of view, since NUE is low and the pathway(s) of autumn N on yield is/are still unidentified.

Autumn $\mathrm{N}$ uptake of at least $10 \mathrm{~kg} \cdot \mathrm{N} \cdot \mathrm{ha}^{-1}$ was required to achieve high seed yields, if no severe stress (severe frost during winter, drought in spring) occurred. 
Acknowledgments: We thank Kirsten Schulz and Cordula Weise for performing the plant sampling and the laboratory analyses.

Author Contributions: Klaus Sieling analyzed the data and wrote the paper. All authors discussed the results and commented on the manuscript.

Conflicts of Interest: The authors declare no conflict of interest.

\section{References}

1. Luteman, P.J.W.; Dixon, F.L. The effect of drilling date on the growth and yield of oil-seed rape (Brassica napus L.). J. Agric. Sci. 1987, 108, 195-200. [CrossRef]

2. Sieling, K.; Böttcher, U.; Kage, H. Sowing date and N application effects on tape root and above-ground dry matter of winter oilseed rape in autumn. Eur. J. Agric. 2017, 83, 40-46. [CrossRef]

3. Lääniste, P.; Jõudu, J.; Eremeev, V.; Mäeorg, E. Sowing date influence on winter oilseed rape overwintering in Estonia. Acta Agric. Scand. 2007, B 57, 342-348. [CrossRef]

4. Balodis, O.; Gaile, Z. Winter oilseed rape (Brassica napus L.) autumn growth. In Proceedings of the Annual 17th International Scientific Conference Research for Rural Development, Jelgava, Latvia, 18-20 May 2011; Latvia University of Agriculture: Jelgava, Latvia; Volume 1, pp. 6-12.

5. Waalen, W.; Øvergaard, S.I.; Åssveen, M.; Gusta, L.V. Winter survival of winter rapeseed and winter turnip rapeseed in field trials as explained by PPLS regression. Eur. J. Agron. 2013, 51, 81-90. [CrossRef]

6. Uzun, B.; Zengin, Ü.; Furat, S.; Akdesir, Ö. Sowing date effects on growth, flowering, oil content and seed yield of canola cultivars. Asian J. Chem. 2009, 21, 1957-1965.

7. Scott, R.K.; Ogunremi, E.A.; Ivins, J.U.D.; Mendham, N.J. The effect of sowing date and season on growth abd yield of oilseed rape (Brassica napus). J. Agric. Sci. 1973, 81, 277-285. [CrossRef]

8. Dejoux, J.-F.; Meynard, J.-M.; Reau, R.; Roche, R.; Saulas, P. Evaluation of environmentally-friendly crop management systems based on very early sowing dates for winter oilseed rape in France. Agronomie 2003, 23, 725-736. [CrossRef]

9. Ogilvy, S.E.; Bastiman, B. The effect of rate and timing of autumn nitrogen on the pre-flowering dry matter production and seed yield of winter oilseed rape. Asp. Appl. Biol. 1992, 30, 413-416.

10. Engström, L.; Stenberg, M.; Aronsson, H.; Lindén, B. Reducing nitrate leaching after winter oilseed rape and peas in mild and cold winters. Agron. Sustain. Dev. 2011, 31, 337-347. [CrossRef]

11. Sieling, K.; Kage, H. Autumnal N fertilization of late sown oilseed rape after minimum tillage. In Proceedings of the 12th International Rapeseed Congress, Wuhan, China, 26-30 March 2007; pp. 375-378.

12. Colnenne, C.; Meynard, J.-M.; Roche, R.; Reau, R. Effects of nitrogen deficiencies on autumnal growth of oilseed rape. Eur. J. Agron. 2002, 17, 11-28. [CrossRef]

13. Chalmers, A.G. Autumn and spring fertiliser nitrogen requirements for winter oilseed rape. Asp. Appl. Biol. 1989, 23, 125-133.

14. Chalmers, A.G.; Darby, R.J. Nitrogen application to oilseed rape and implications for potential leaching loss. Asp. Appl. Biol. 1992, 30, 425-430.

15. Scott, R.K.; Ogunremi, E.A.; Ivins, J.U.D.; Mendham, N.J. The effect of fertilizers and harvest date on growth and yield of oilseed rape sown in autumn and spring. J. Agric. Sci. 1973, 81, 287-293. [CrossRef]

16. Zhao, F.J.; Evans, E.J.; Bilsborrow, P.E.; Syers, J.K. Influence of sulphur and nitrogen on seed yield and quality of low glucosinolate oilseed rape (Brassica napus L.). J. Sci. Food Agric. 1993, 63, 29-37. [CrossRef]

17. Bilsborrow, P.E.; Evans, E.J.; Zhao, F.J. The influence of spring nitrogen on yield, yield components and glucosinolate content of autumn-sown oilseed rape (Brassica napus). J. Agric. Sci. 1993, 120, $219-224$. [CrossRef]

18. Reau, R.; Wagner, D.; Palleau, J.P. End of winter diagnosis: Winter rapeseed and nitrogen fertilization. In Proceedings of the Third Congress of the European Society for Agronomy, Podova, Italy, 18-22 September 1994; European Society for Agrnonomy: Podova, Italy; pp. 220-221.

19. Henke, J.; Sieling, K.; Sauermann, W.; Kage, H. Analysing soil and canopy factors affecting optimum nitrogen fertilization rates of oilseed rape (Brassica napus). J. Agric. Sci. 2009, 147, 1-8. [CrossRef]

20. Makowski, D.; Maltas, A.; Morison, M.; Reau, R. Calculating N fertilizer doses for oil-seed rape using plant and soil data. Agron. Sustain. Dev. 2005, 25, 159-161. [CrossRef] 
21. Mendham, N.J.; Shipway, P.A.; Scott, R.K. The effects of delayed sowing and weather on growth, development and yield of winter oil-seed rape (Brassica napus L.). J. Agric. Sci. 1981, 96, 389-416. [CrossRef]

22. Barraclough, P.B. Root growth, macro-nutrient uptake dynamics and soil fertility requirements of a high-yielding winter oilseed rape crop. Plant Soil 1989, 119, 59-70. [CrossRef]

23. Sieling, K.; Schröder, H.; Hanus, H. Mineral and slurry nitrogen effects on yield, $\mathrm{N}$ uptake, and apparent $\mathrm{N}$ use efficiency of oilseed rape (Brassica napus). J. Agric. Sci. 1998, 130, 165-172. [CrossRef]

24. Shepherd, M.A.; Sylvester-Bradley, R. Effect of nitrogen fertilizer applied to winter oilseed rape (Brassica napus) on soil mineral nitrogen after harvest and on the response of a succeeding crop of winter wheat to nitrogen fertilizer. J. Agric. Sci. 1996, 126, 63-74. [CrossRef]

25. Beaudoin, N.; Saad, J.K.; van Laethem, C.; Machet, J.M.; Maucorps, J.; Mary, B. Nitrate leaching in intensive agriculture in Northern France: Effect of farming practices, soils and crop rotations. Agric. Ecosyst. Environ. 2005, 111, 292-310. [CrossRef]

26. Rathke, G.W.; Behrens, T.; Diepenbrock, W. Integrated nitrogen management strategies to improve seed yield, oil content and nitrogen efficiency of winter oilseed rape (Brassica napus L.): A review. Agric. Ecosyst. Environ. 2006, 117, 80-108. [CrossRef]

27. Sieling, K.; Kage, H. N balance as an indicator of N leaching in an oilseed rape-Winter wheat-Winter barley rotation. Agric. Ecosyst. Environ. 2006, 115, 261-269. [CrossRef]

28. Cramer, N. Raps-Züchtung, Anbau und Vermarktung von Körnerraps; Verlag Eugen Ulmer: Stuttgart, Germany, 1990.

29. Sieling, K. Unpublished work. 2017.

30. Sieling, K. Growth stage-specific application of slurry and mineral $\mathrm{N}$ to oilseed rape, wheat and barley. J. Agric. Sci. 2004, 142, 495-502. [CrossRef]

31. Henke, J.; Breustedt, G.; Sieling, K.; Kage, H. Impact of uncertainty on the optimum nitrogen fertilization rate and agronomic, ecological and economic factors in an oilseed rape based crop rotation. J. Agric. Sci. 2007, 145, 455-468. [CrossRef]

32. Bundesgesetzblatt. Düngeverordnung. Bekanntmachung der Neufassung der Düngeverordnung, Bundesgesetzblatt. Available online: https://www.bgbl.de/xaver/bgbl/start.xav?start=//*\%5B@attr_ id=\%27bgbl107s0221.pdf\%27\%5D\#_bgbl_\%2F\%2F*\%5B\%40attr_id\%3D\%27bgbl107s0221.pdf\%27\%5D_ _1487932661132 (assessed on 11 November 2007).

33. Sieling, K.; Kage, H. Efficient N management using winter oilseed rape: A review. Agron. Sustain. Dev. 2010, 30, 271-279. [CrossRef]

34. Sieling, K.; Schröder, H.; Finck, M.; Hanus, H. Yield, N uptake, and apparent N-use efficiency of winter wheat and winter barley grown in different cropping systems. J. Agric. Sci. 1998, 131, 375-387. [CrossRef]

35. Rossato, L.; Lainé, P.; Ourry, A. Nitrogen storage and remobilisation in Brassica napus L. during the growth cycle: Nitrogen fluxes within the plant and changes in soluble protein patterns. J. Exp. Bot. 2001, 52, 1655-1663. [CrossRef] [PubMed]

36. Ulas, A.; Behrens, T.; Wiesler, F.; Horst, W.J.; Schulte auf'm Erley, G. Does genotypic variation in nitrogen remobilisation efficiency contribute to nitrogen efficiency of winter oilseed-rape cultivars (Brassica napus L.)? Plant Soil 2013, 371, 463-471. [CrossRef]

37. Girondé, A.; Poret, M.; Etienne, P.; Trouverie, J.; Bouchereau, A.; Le Cahérec, F.; Leport, L.; Orsel, M.; Niogret, M.-F.; Deleu, C.; et al. A profiling approach of the natural variability of foliar $\mathrm{N}$ remobilization at the rosette stage gives clues to understand the limiting processes involved in the low $\mathrm{N}$ use efficiency of winter oilseed rape. J. Exp. Bot. 2015, 66, 2461-2473. [CrossRef] [PubMed]

38. Zar, J.H. Biostatistical Analysis, 5th ed.; Prentice Hall: Upper Saddle River, NJ, USA, 2009.

(c) 2017 by the authors. Licensee MDPI, Basel, Switzerland. This article is an open access article distributed under the terms and conditions of the Creative Commons Attribution (CC BY) license (http:/ / creativecommons.org/licenses/by/4.0/). 